\title{
COMPATIBILITY STUDIES OF INTERSPECIFIC IN VITRO MICROGRAFTING OF AGARWOOD (Aquilaria malaccensis LAMK.)
}

\author{
NURITA TORUAN-MATHIUS*, JONNER SITUMORANG, DEWI RACHMAWATI \& \\ ANIDA
}

Biotechnology and Plant Breeding, SEAMEO BIOTROP, Bogor, Indonesia

\begin{abstract}
Aquilaria spp produced agarwood as nonwood forest production, and has high economic value. A. malaccensis is susceptible to white rot diseases and termites. On the other hand most of the community plantations are a mixed culture with rubber trees, oil palms and with high risk of contamination causing white root diseases. Besides that, vegetative propagation by cuttings, stumping or air layering are still very difficult with low percentage of growth. The objectives of this research were to analyze the best suitable micrograft type, changes of SDS-PAGE protein band patterns of compatible and incompatible micrografts with several combinations of gaharu planlets in in vitro condition, and histology of union area between rootstocks and scion. The results showed that wedge or $\mathrm{V}$ type was the best of the micrografs. MS medium with the addition of $3 \mathrm{mg} / \mathrm{L} \mathrm{IBA}$ was the best medium for gaharu planlet growth after micrografting. Acclimatization was conducted in husk chacoal and top soil (1:1) medium and grown under plastic house of $70 \%$ shading with paranet. Compatible combination $(\mathrm{Ac} / \mathrm{Am})$ of micrografting showed that anatomy structure of union area is the same as anatomy structure of non micrograftd planlet. While incompatible (Gv/Am) micrografting produced necrotic layer growth from pith and parenchymateous tissues of the wood in union area along the middle of radial shoot. Recovery period of union area between stocks and scion is initiated by callus formation from the pith and parenchymatous tissues of the wood. Callus will differentiate into mature cells or tissue and become combined phloem and xylem vessels between rootstocks and scion. SDS-PAGE protein band pattern on compatible combination was the same as plants originated from seedlings. While, incompatible combination produced new protein bands with molecular weight around 21 and $30 \mathrm{kD}$.
\end{abstract}

Key words : Agarwood, Aquilaria spp, micrografting in vitro, incompatible micrografting, SDSPAGE protein, incompatible histology.

\section{INTRODUCTION}

A. malaccensis, is a famous species for production of good-quality agarwood. Agarwood is an inducible secondary metabolite caused by interaction between defence materials like phytoalexin of gaharu trees against compatible pathogen of cells in woody

*Corresponding author: nurita-toruan@smart-tbk.com 
tissues (Van der Plank 1978; Kunoh 1990; Rahman \& Basak 1980; Parman et al. 1996). This secondary metabolite resin is not secreted from trees like other resins or gum, but accumulated in infected stems or branches. This phenomenon causes the white and smooth part of wood turns to be dark and hard. This wood becomes heavier and fragrant if it is burned (Hou 1960; Anonim 2002; Subansenee et al. 1985).

Gaharu is of high economic importance in Asia due to its use for the production of incense, perfumes and traditional medicines. A. malaccensis is recognized on the IUCN red list as critically endangered and considered to be at risk from overexploitation. All species of Aquilaria were included on the Appendix II list of the Convention on International Trade in Endangered Species of Wild Fauna and Flora (CITES) in 1994 (CITES 2003) to improve control of commercial gaharu trade in all participating countries.

To prevent $A$. malaccensis to become an endangered species, Indonesia has compiled a National program for sustainable agarwood production by planting of this species in several provinces through government project and community participation (Suparman 2006). These programs faced problems because A. malaccensis is susceptible to white root diseases and termites. On the other hand, most of the community plantations are a mixed culture with rubber trees, oil palms and with high risk of soil contamination causing white rot diseases; $A$. malaccensis is a relatively slow-growing plant compared with other Aquilaria species; Recalcitrant seed with low viability, hand-sown seeds have germination rate $(67 \%$ for those planted immediately, decreasing to $47 \%$ for those sown after 1 week).

To solve these problems in vitro micrografting between $A$. malaccensis as a scion and other species of Aquilaria or Gyrinops as a rootstock, or interspecific micrografting could be used for propagation. Toruan-Mathius et al. (2006 b) reported that SEAMEO BIOTROP has succeeded to develop tissue culture technique for propagation of $A$. malaccensis, A. crassna, A. becariana and Gyrinosp verstigii from selected mother plants, acclimatized and planted under field conditions. These techniques are used as a basis for in vitro micrografting.

In vitro micrografting: Shoot-tip grafting in vitro (STG) consists of grafting, under aseptic conditions, a small shoot tip onto a young seedling or planlet root stocks growing in vitro. The technique has the following steps: rootstock preparation, scion preparation, grafting procedure, growing grafted plants in vitro, and transferring to soil.

Possibility of micrograft less differentiates shoot tip tissue may also help in reducing compatibility problems between scion and stock (Jonart 1986).

Several reports have described the application of in vitro and in vivo micrografting that may provide several advantages such as rejuvenation of mature tissues, year round plant production, enhanced compatibility studies and correlative relations between root stocks and scions, make specific genotypic combinations to increase productivity, and extend ecological limits of a particular plant species or cultivar to tolerate edaphic conditions (Richardson et al. 1996; Hartmann et al. 1997; Estrada-Luna et al. 2002; Sobhana et al. 2001; Sanjaya et al. 2006). Toruan-Mathius et al. (2006a) have succeeded to use in vitro and in vivo interspecific micrografting of Cinchona ledgeriana as a scion onto $C$. succirbura as a rootstock to avoid white root disease. Under field condition, in vitro micrografting grows faster than that of in vivo grafting.

Da Costa et al. (1991) observed that production of plants grafted on Robusta coffee was three to four times higher than that of nongrafted plants. In addition it is 
also used to increase resistance to soilborne parasites or soil-borne diseases caused by pathogens such as Fusarium oxysporum. Grafting is also commonly used for fruit trees and in silviculture (i) to improve tree adaptation to unfavorable soil or climatic conditions, (ii) to enhance water and nutrient uptake, (iii) to increase plant vigour and extend duration of economic harvest time, and (iv) to shorten the breeding period by limiting the breeding objective for resistance to soil-borne diseases and nematodes in root stock. These findings suggest that the existence of this technique is an effective means of rapid and true-to-type multiplication of desired $A$. malaccensis genotypes.

The objectives of this study were: (i) to determine the appropriate and reliable micrografting techniques for agarwood planlets; (ii) to determine survival, growth, rootstock suckering, and short-term compatibility of $A$. malaccensis scion on several species of rootstocks under in vitro conditions, and (iii) to characterize graft incompatibility based on histological and biochemical aspects of grafting.

\section{MATERIALS AND METHODS}

The study consisted of rootstock preparation, scion preparation, (a) In vitro micrografting, (b) analysis of compatibility by histology and (c) electrophoresis SDSPAGE protein of stem from scion.

\section{Plant materials}

A. malaccensis B23 line used as scions were micropropagated following techniques established by Situmorang (2000). Axillary buds excised from young planlets $(3-5 \mathrm{~cm}$ long) were initially used as explants and induced to develop shoots using Murashige and Skoog (1962) basal salt formulation medium adjusted at $\mathrm{pH} 5.7$ and supplemented with $5.0 \%$ sucrose and $0.6 \%$ bacto agar. BA (6-benzyl aminopurine) of $1.0 \mathrm{mg} / \mathrm{L}$ was added for shoot induction and proliferation cultures. Adventitious roots developed in MS medium with the addition of $3 \mathrm{mg} / \mathrm{L}$ IBA (Indole Butyric Acids). Planlets of vigorous A. crassna, A. filaria and Girynops verstigii as stocks were propagated by tissue culture the same as for planlet scions.

All cultures were grown in a culture room with light of $100 \mu \mathrm{mol} \mathrm{m} \mathrm{m}^{-2} \mathrm{~s}^{-1}$ photosynthetic photon flux density (PPFD) cool white fluorescent lamps at planlet level and photoperiod of $16 \mathrm{~h}$. Temperature was maintained at $27 \pm 2{ }^{\circ} \mathrm{C}$.

\section{Micrografting}

Under aseptic conditions, shoots of uniform length and diameter were selected from in vitro culture and used as rootstocks and scions in micrografting. Stainless silver blades mounted on a handle were used for cutting the plant material. Freshly picked shoot tips and in vitro regenerated shoot tips were used as microscions. To prepare the initial scions of the micrografts, the leaves from those portions were eliminated, and four types of grafting were made in each of their basal parts.

For micrografting, the following method was used. When the stem axis of the plantlets reached a length of about $2 \mathrm{~cm}$ the upper $1.0 \mathrm{~cm}$ of the tips were excised and used as scion, while remaining portion was used as rootstock. In the first experiment four types of grafting viz., a) wedge (V), (b) horizontal - cut grafting, (c) slant-cut grafting (/) 
and (d) cleft grafting (I) (Fig.1) were made in the rootstock and scion. The scions were placed in the incisions made in the rootstock with both the cut surfaces in good physical contact (Fig. 1). The stock and scion were held together at the point of graft with sterile $(1 \times 1 \mathrm{~cm})$ light aluminum foil.

For optimizing the method of micrografting in vitro plant materials and as scion only B 23 and $A$. crassna as a rootstock were used. On the other hand, for compatibility studies three clones of $A$. malaccensis as scion and three species as rootstocks were used, with the best method of micrografting, and as a control the same species of scion and rootstocks were used. The percentage of successful and unsuccessful grafts was determined 30 days after grafting and in vitro culture.

All planlets of graft treatments were cultured in MS medium $+3 \mathrm{mg} / \mathrm{L}$ IBA for rooting. After three months the growth of scion as a result of graft union was observed. For incompatibilities studies, the combination of scion-stock i.e. A. malaccensis as scion and A. filarial, A. crassna, Gyrinops verstigii as stocks could be used, while as control the same species of scions and rootstocks were used. Cultures were incubated in light culture room (16 hrs/days) with $\mathrm{Rh} 70-80 \%$.

a

(i)
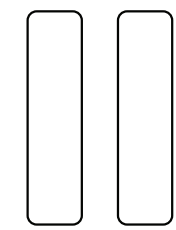

b

C

d

(ii)
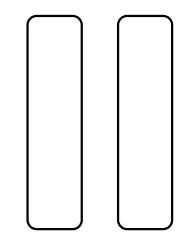

(iii)
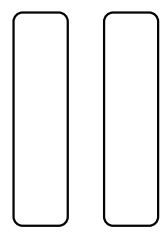

(iv)
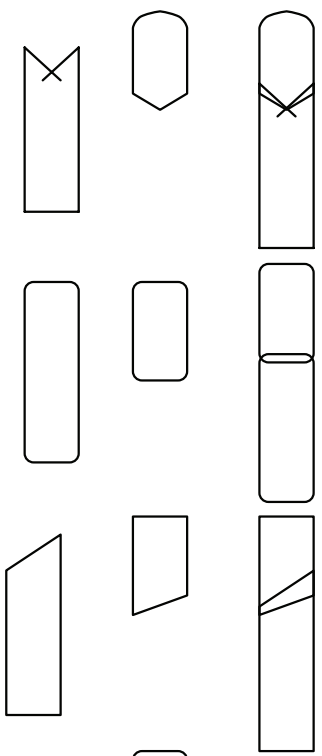
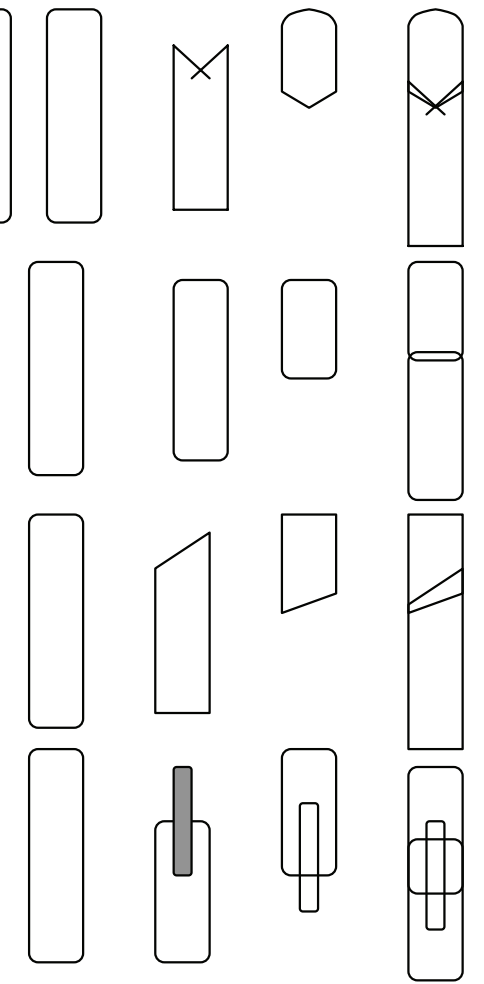

Figure 1. In vitro micrografting between scion of $A$. malaccensis planlets with rootstocks of several species of Aquilaria sp and G. verstigii, using (i) wedge, (ii) horizontal, (iii) slant, and (iv) cleft grafts. a. micropropagated shoots, b. rootstock, c. scion, and d. methods of grafts. 


\section{Growth analysis}

The in vitro micrografting success rate was determined 6 weeks after grafting by recording the number of scions still alive out of all individual treatments. Number of leaves were also recorded and measured for each sample, 2 months after the date of micrografting, and recorded continuously for every month during 8 months observations. At the end of the experiment, all plants were carefully removed to study their root systems. For five plants from each graft combination and the control, the stem was cut crosswise for macroscopic observation of graft union or analysis of compatibility.

\section{Experimental design}

Combination of stock-scion viz: A.malaccensis/A.malaccensis (control 1), $A$. crassnal A. crassna (control 2), A. filarial A. filaria (control 3); A. malaccensis/ A. crassna; A. malaccensis/ A. filaria was used. Experiments used Completely Randomized Design of $1 \times 3$ units with 15 replicates.

\section{Analysis of compatibility}

Analysis of compatibility between scion and rootstocks studies by histology and electrophoresis SDS PAGE protein of graft union, were conducted for in vitro micrografting.

\section{Histology of graft}

A histological technique was used to observe the graft union of every combination of root stock/scion. The graft union was cut into segment of $2 \mathrm{~cm}$ long and microtome was used to cut $25 \mu \mathrm{m}$ slices from the segments. The samples were fixed for $24 \mathrm{~h}$ in solution of FAA and then dehydrated in an ethanol series (50-70-80-90-95-100-100\%) for $30 \mathrm{~min}$. each. Safranin (2\%) was added in 70\% ethanol and fast green (1\%) in 100\% ethanol for 15 seconds. The slices were placed in a solution of 1 absolute ethanol: 1 xylene for 30 seconds and then in pure xylene ( $2 \mathrm{x}$ for $30 \mathrm{~min}$. each), before being examined under the microscope (Esau 1965).

\section{Electrophoresis SDS-PAGE protein}

Total protein was extracted from scion shoot $(2 \mathrm{~cm}$ above graft line) by frozing in liquid nitrogen and stored at $-40^{\circ} \mathrm{C}$. Plant tissues were homogenized in a mortar in the presence of liquid nitrogen and extracted using buffer containing $5 \mathrm{mM}$ Tris $\mathrm{HCl}$, $\mathrm{pH} 8,500 \mathrm{mM} \mathrm{NaCl}, 2 \mathrm{mM}$ ascorbic acid, $0.5 \mathrm{mM}$ phenylmethylsulphonyl fluoride and $1 \mathrm{mM}$ dithiotreitol (Laemmli 1970). The homogenate was heated at $80^{\circ} \mathrm{C}$ for 10 min. and centrifuged at $17.000 \mathrm{~g}$. Supernatant were thawed and heat stable proteins were quantified by the binding-dye assay (Bradford 1976). Protein was separated by 10-15\% polyacrilamide gradient gels. Heat stable proteins $5-15 \mu$ g were loaded in each well with discontinuous buffer systems (Laemmli 1970) using a Mini protean 3-electrophoresis cell (Bio-Rad, Hercules, CA, USA). Gel lanes were loaded with equal amounts of perceptible counts; low molecular weight protein standards (Bio-Rad) were run as size markers.

Electrophoresis run with constant current of $75 \mathrm{~mA}$ was applied per gel. During electrophoresis the voltage increased from about 300 to $600 \mathrm{~V}$. A $0.025 \mathrm{M}$ tris-glycine buffer ( $\mathrm{pH}$ 8.6) was used as the electrode buffer. When the tracking dye had migrated to the bottom of gel (after approximately $3.5 \mathrm{hrs)} \mathrm{electrophoresis} \mathrm{was} \mathrm{stopped.} \mathrm{Gels} \mathrm{were}$ 
stained with Commasie brilliant blue. After staining gels were fixed in solution containing methanol, glacial acetic acid and distilled water with the ratio of 4:1;15 (v/v/v) for 15 min. and photographed, then gels were wrapped with cellophane for documentation.

The effect of stock on scion was studied by the formation of new protein band or disappeared protein band compared with control (non micrografting and micrografting scion-stock with the same species).

\section{Statistical analysis}

All data were subjected to one-way analysis of variance (ANOVA) using SAS version 6.12 (SAS Institute 1996). For categorical data, the normality of residuals and homoscedasticity were verified to fulfill the requirements for ANOVA. Duncan's multiple range test was used for mean separation. The differences were considered significant at $\mathrm{P}$ $\leq 0.05$.

\section{RESULTS AND DISCUSSION}

\section{In vitro micrografting}

The type of graft and nature of support significantly influenced the success of micrograft. Wedge or $\mathrm{V}$ graft gave the most successful micrografts followed by cleft graft method (Tabel 1). V graft may provide a better surface for the contact of stock and scion providing good cambial joining at the graft union. It was shown that $\mathrm{V}$ type of micrograft also gave highly significant difference on grafting success, except on the first week of incubation because of callus formation (Table 2). A good result was obtained with micrograft $\mathrm{V}$ type, which gave faster growth compared to cleft graft, caused by $\mathrm{V}$ graft which have high levels of graft union (Table 2). Micrografting of gaharu planlet with $\mathrm{V}$ graft in combination between rootstocks and scion Ac/Am and Am/Am showed the same vigour (Fig. 2).

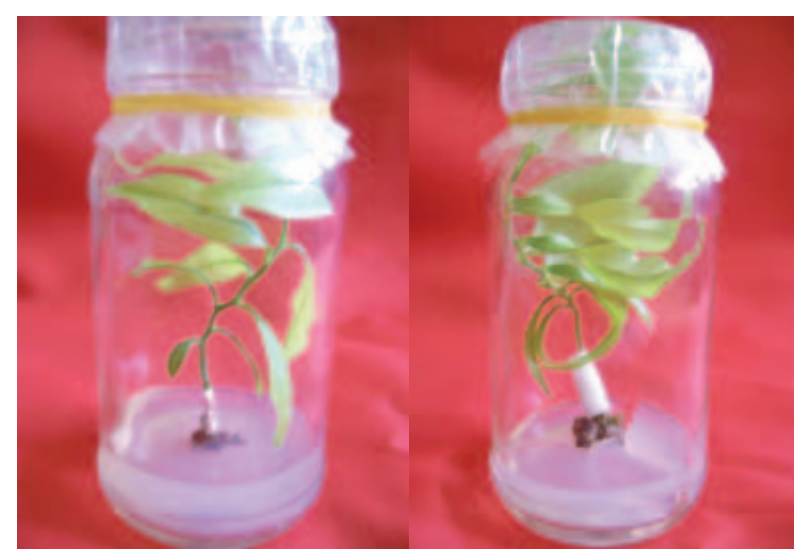

(a)

(b)

Figure 2. Micrografting of gaharu planlet with $\mathrm{V}$ type in combination between rootstocks and scion: (a) Ac/Am, and (b) Am/Am. Ac-Aquilaria crassna; Am - Aquilaria malaccensis 
Interspecific in vitro micrografting of agarwood - N. Toruan-Mathius et al.

Table 1. Effect of micrografting techniques on union and growth of scion

\begin{tabular}{lcc}
\hline \multicolumn{1}{c}{ Method of grafting } & Number of grafts & Grafting success (\%) \\
\hline Wedge (V graft) & 25 & $98,5 \mathrm{a}$ \\
Horizontal & 20 & $25.6 \mathrm{c}$ \\
Slant & 25 & $28,6 \mathrm{c}$ \\
Cleft grafts & 25 & $80,7 \mathrm{~b}$ \\
\hline
\end{tabular}

Estrada-Luna et al. (2002) reported that the best method for in vitro micrografting of prickle cactus (Opuntia spp) were horizontal and wedge grafts. The firm contact between rootstock and scion is extremely important at the graft junction to get fusing between them and callus formation. Lukman et al. (2005) found that micrografting of two different species (mundo and manggis) with $\mathrm{V}$ type, gave $76 \%$ succesful graft rate when the shoot tips were used directly as microscions in in vitro studies. Oda (1995) said that micrografting with $\mathrm{V}$ type will gave a firm and faster union between stocks and scion.

Tirtawinata (2003) explained that the success rates of micrograft are highly dependent upon the cambium union of rootstocks and scion. Partial contact of rootstock and scion cambium will contribute to unsuccesful joining. These cases are described as "translocated" graft incompatibilities (Estrada-Luna et al. 2002) According to Hartmann et al. (1997) callus formation occurred as parenchym cells in a process of wound recovery. These callus will differentiate into cambium, xylem and phloem. These vessels are used for transportation of nutrition and photosyntate. Kala et al. (2002) reported that in vitro micrografts rubber begin to grow weeks after micrografting. Rifa'i (2003) found callus formation up to three months after micrografting.

Tabel 2. The effect of micrograft types on leaf number of 1-8 week- old planlets after micrografting.

\begin{tabular}{|c|c|c|c|c|c|c|c|c|}
\hline \multirow{2}{*}{$\begin{array}{l}\text { Combination and } \\
\text { type of micrograft }\end{array}$} & \multicolumn{8}{|c|}{ On weeks .... } \\
\hline & 1 & 2 & 3 & 4 & 5 & 6 & 7 & 8 \\
\hline $\mathrm{Ac} / \mathrm{Am}-\mathrm{V}$ & 0 & $0.4 \mathrm{a}$ & $1.56 \mathrm{a}$ & $2.28 \mathrm{a}$ & $3.00 \mathrm{a}$ & $3.88 \mathrm{a}$ & $4.56 a$ & $5.08 a$ \\
\hline Ac/Ac-L & 0 & $0.71 b$ & $1.20 \mathrm{~b}$ & $1.58 b$ & $1.72 b$ & $2.95 b$ & $2.14 \mathrm{~b}$ & $2.23 b$ \\
\hline $\mathrm{Am} / \mathrm{Am}-\mathrm{V}$ & 0 & $1.27 \mathrm{a}$ & $2.24 \mathrm{a}$ & $3.00 \mathrm{~b}$ & $3.84 \mathrm{a}$ & 4.08a & $4.92 \mathrm{a}$ & $5.48 a$ \\
\hline $\mathrm{Am} / \mathrm{Gv}-\mathrm{L}$ & 0 & $0.85 b$ & $1.23 \mathrm{~b}$ & $2.08 b$ & $2.84 b$ & $3.52 \mathrm{~b}$ & $4.20 \mathrm{~b}$ & $4.84 \mathrm{~b}$ \\
\hline Ac/Ac-V & 0 & $1.14 \mathrm{a}$ & $2.00 \mathrm{a}$ & $2.60 a$ & $3 ., 52 a$ & $4 ., 00 \mathrm{a}$ & 4.68,a & $5.32 \mathrm{a}$ \\
\hline CL/CL-L & 0 & $0.71 b$ & $1.16 \mathrm{~b}$ & $2.00 \mathrm{~b}$ & $2.40 \mathrm{~b}$ & $3.24 \mathrm{~b}$ & $4.00 \mathrm{~b}$ & $4.48 b$ \\
\hline Respons & tn & $*$ & $*$ & $*$ & $*$ & $*$ & $*$ & $*$ \\
\hline
\end{tabular}

Explanation ns : not significantly ; *.Significantly different. Numbers followed by the same letter in the same column are not significantly different according to Duncan test $\mathrm{P}<0,05$ 


\section{Acclimatization}

The average of planlets survived after acclimatization in husk charcoal : sterile top soil (1:1) after one month incubation was 90\% (Tabel 3). Gunawan (1992) reported that planlet from in vitro culture i.e. has wax layer on undeveloped cuticula, limited shoot lignification, number of leaves palisade cells very low, undeveloped xylem, disfunction of stomata caused high transpiration it caused the scion become sensitive to evapotranspiration, attack of fungi and soil bacteria, and also to high light intensity. That is why planlets should be acclimatized before transfering into the field.

Table 3. Survival percentage of gaharu planlet after acclimatization two months grown in plastic house.

\begin{tabular}{lc}
\hline Combination and Graft type & \% of survived planlet \\
\hline Ac/Am $-\mathrm{V}$ & $92 \mathrm{~b}$ \\
Ac/Ac $-\mathrm{V}$ & $90 \mathrm{~b}$ \\
Am/Am $-\mathrm{V}$ & $90 \mathrm{~b}$ \\
Ac/Am -cleft & $60 \mathrm{a}$ \\
Ac/Ac -cleft & $66 \mathrm{a}$ \\
Am/Am -cleft & $65 \mathrm{a}$ \\
\hline
\end{tabular}

Explanation: Numbers followed by the same letter in the same column are not significantly different according to Duncan test $\mathrm{P}<0.05$

\section{Histology of micrografts}

The results showed that anatomy structure of gaharu shoot is the same as anatomy structure of plantlet shoot of another Dicotyledone plant which consisted of phloem, cambium and xylem. Cambium was radially in between of phloem and xylem vessels. The inner part of cambium develops into xylem vessels which function as a transportation of water and nutrition from roots to upper parts. Outside the cambium is phloem which functions as a transportation of photosyntate to ground parts of plant.

Our observation revealed five development stages during graft union formation: development of necrotic layer, proliferation of callus bridge at the graft interface, differentiation of new vascular cambium, restoration of new vascular tissue, and restoration of the continuity of the epidermis at the graft union. Unions between parenchymatous tissues have been confirmed 2-3 weeks after grafting. Fifteen days after grafting parenchyma unions occur in all micrografts that have prospects of further development. Only cells newly formed after grafting are able to unite.

The first unions occur between cells originating from tissues outside the cambial region. In side-slit grafts with radial incision in the bark of the rootstocks, the first union developed between callus from the rootstock cambial region in the barks flap, and callus from cortex, phloem rays and pith of the scion. Trial incision on the rootstock unions also occurs at the incision face in a way similar to that of veneer side grafts. Union of newly formed cells may develop independently of the kind of originial tissues (Fig. 3a \& 3b). 


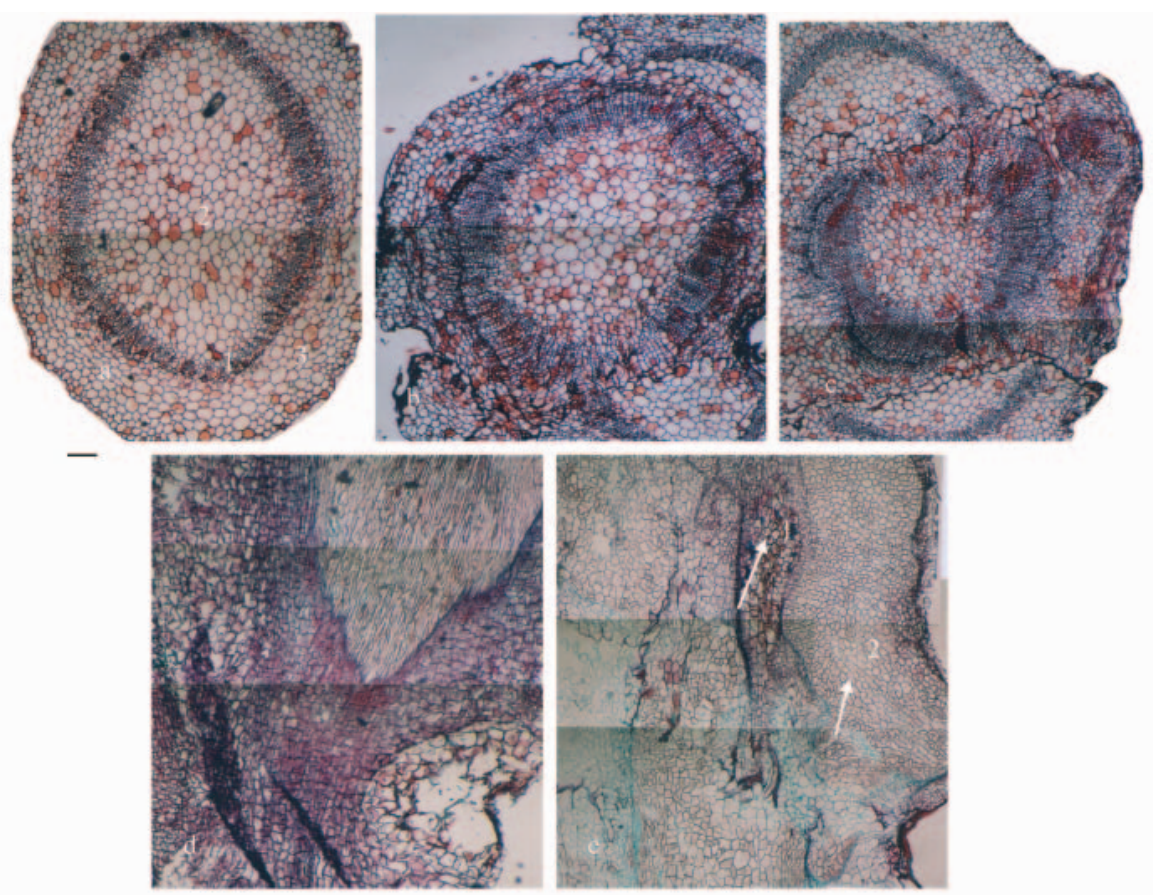

Figure 3. Histology union area of compatible and incompatible micrograft
(a, b \& c) radial cross section of stem at union area.
(a). Non micrografted stem, (b) union area of compatible micrograft,
(c) union area of incompatible micrograft
(d \& e) longitudinal cross section of stem union area.
(d) union area of compatible micrograft, (e) union area of incompatible micrograft. (a). 1- cambium, 2- pericycle, 3- cortex

(e) $\rightarrow 1$ - necrotic cells; $\rightarrow 2$ - callus; - Bars $(40 \mu \mathrm{m})$

Histological investigations concluded that callus bridging between scion and the rootstock was completed three weeks after micrografting and that both partners took part in the development of the callus. Differentiating xylem elements within the callus bridge were observed by the fourth week but no bridging of the graft union was achieved at this stage. Noticeably, each partner established new vascular system outside the callus bridge, directed towards the others. Hartmann et al. (1997) explained that callus is a group of parenchym cells which has developed around wounded tissues. Growth of parenchym cells is a initial phase of callus formation in union area of stocks and scion. Parenchym cell has high ability to divide and develop into mature cells. Cell development and anatomy of planlet will change, and its function of each tissue/cells one to another is also different. Undifferentiated tissues have different functions compared to differentiated tissues. Callus will differentiate into mature cells or tissue and become a combined tissue between rootstocks and scion. Callus growth was found from the combination of Gv/Am and Gv/Amc (Fig. 3 b, c \& d) but different with the seedling or Am/Am (Fig. 3). It was shown that the rootstock affected the growth of the scion, changes the morphology and 
anatomical structure of the scion. In contrast, the scions have little effect on rootstock growth.

Mismatch of phloem fiber bundles has an important effect on graft success (Fig $3 \mathrm{e})$. On the whole, the rootstocks produce a large volume of callus before union than the scions but leaf traces adjacent to cut surfaces of the scions cause locally larger formation of callus. Rays that have been cut far from the phloem usually form more callus than those which have been cut close to the cambium. The boundary between phloem and cortex is a very active zone of growth.

The cambial region plays a subordinate role as a callus producer in veneer side grafts in the rootsocks of $\mathrm{V}$ graft. However, the loose bark from the wood in the cambial region and the cells produce vigorous callus formation (Erea et al. 2001). This process is initiated by ray cells, but soon the major portion of the cambial cells participate if they are undamaged by grafting. Callus formation from the pith and from parenchymatous tissues of the wood occurs only in union area. The pith of the scion is particularly active when cut.

Since the cambium rootstocks had already entered an active stage at grafting and the rootstocks have water and nutrients supply higher than that of the scion, its cambium will be able to deposit several new rows of tracheids up at the time when union is possible. This means that the cambium is forced to move from scion cambium which has been placed in front, but which is catching another cambium that has been placed outside (Fig 3).

The first unions of vascular tissues in veneer side grafts are often found between the stock flap and tissues situated on the short cut surface of the scion leaf traces which appear to play an important role in the establishment of vascular connections. The cambial unions in the innermost corner of side slit grafts become complex depending on the mutual position of the tissues of the grafts components. It is not necessary for the space between the wood surfaces of the graft components to be filled with callus tissues, above the uppermost point of contact with the scion. Thus the wound caused is callused over from all sides in the same manner as in cut branch.

Rifa'i (2003) found that callus formation at union area still continues up to three months after micrograft. Tirtawinata (2003) reported differentiation process of new cambium occurred after three months of micrografting. After fourty days to 6 months of union area will make apple micrografts become firm (Richardson 1996).

Estrada-Luna et al. (2002) explained that compatible micrograft growth of scion planlet is very vigourous, while the incompatible one is dwarfish. In walnut (Junglans regia) union of vascular tissues have been confirmed after about three weeks in wellmatched grafts. When the matching has not been well done, union may require 5-6 weeks. In well-matched grafts it is common that divisions in the cambial region are able to serve in the union of vascular tissues almost at once. Only a small number of short, irregular cells are then formed. When the cambial region is located further apart, they spread through intermediate parenchyma tissues toward each other by joining from one cell to the next.

Heteroplastic or interspecific micrografting is used in fruit tree breeding to produce early and abundant flowering small trees. The same effect also occurs when grafting forest trees for seed orchards. In order to avoid nematode damage to roots of Coffea arabica L. in Latin America, a common practice is to apply interspecific grafting on C. canephora var. 
Robusta (Pierre) rootstocks. Villain et al. (1996) observed that with heavy Pratylenchus sp, infestations, production of Arabica plants grafted on a C. canephora var. Robusta $(2 \mathrm{n}=2 \mathrm{x}=44)$ rootstock was four times higher compared to nongrafted plants.

\section{Electrophoresis SDS - PAGE protein}

The results showed that leaf protein of scion tested has molecular weight of 14 - $45 \mathrm{kD}$. Generally SDS-PAGE protein band patterns of scion are the same with planlet control or non micrografting, except from Am/Amc and Am/Gv. Two of the small protein molecules, 21 and $30 \mathrm{kD}$ were found only in these combinations (Fig. 4). There are several basic strategies for identifying stocks/scion interactions at the biochemical level.

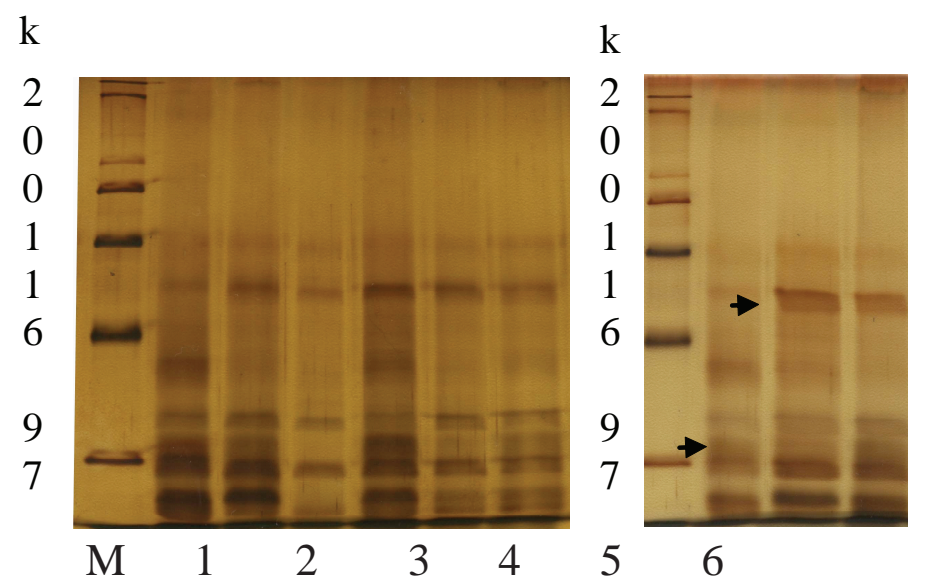

Figure 4. Electrophoregram leaf protein of scion as a result of micrografting in vitro. M. Marker; 1. Am; 2. Amc; 3. Gv; 4. Am/Am; 5. Amc/Amc; 6. Gv/Gv; .Am/Amc; 8. Am/Gv; 9. Amcl Gv

The most important step in identifying a biochemical basis for stocks/scion interaction is verifying that there is caused- and- effect- relationship between the present particular proteins.

New protein formation in incompatible rootstocks/scion may be regulated by proteins because these molecules constitute the machinary of cell metabolism. When examining a development change of varietal difference in a metabolic process, the cause of the change or difference is most commonly a change in the presence, stability, or activity of particular proteins.

Ji-Zhong et al. (2002) reported that incompatible micrografting of apple caused an increase in POD and IOD enzymes activities. These enzymes controlled auxin translocation from root to upper parts of plant. Holbrook et al. (2002) found that on compatible micrografts there was a positive relationship between rootstocks and scion. These conditions have been correlated with nutritions distributions, translocation of water and nutrition, and regulation of hormon transportation. Raghothama (1999) explained that in 
compatible micrograft of Arabidopsis the relationship of source and sink between stocks and scion is normal. Incompatible micrografts of peach and plum planlet affected protein and amino acids content of the whole tissues. Bertrand and Etienne (2001) said that the synthesis of a conserved set of proteins, heat shock proteins, in response to water stress caused inhibition of translocation of nutrient and water. Toruan-Mathius et al. (1999) found that variations of protein band patterns in union area of micrograft rubber plant are caused by different interactions between micrograft combinations. Erea et al. (2001) explained that micrograft can be used as early detection of compatible and incompatible combination of rootstocks and scion in plants propagated by micrografts. It was clearly distinguishable that protein banding patterns significantly have a relationship with the success or failure of grafting.

In vitro micrografts usually fail due to incompatibility between stock and scion, oxidative browning of cut surfaces, poor contact or poor development of the root system (Toruan-Mathius et al. 2006a; Moor 1991). Sobhana et al. (2001) studied about physiological and biochemical aspects of stock-scion interaction in Hevea brasiliensis and found that assimilation rate of scion is being influenced by the rootstock. The considerable $\mathrm{CV}$ observed between the individual plants within clone in total soluble sugars, reducing sugars, phenol and amino acid contents, also indicated the existence of stock-scion interaction. Toruan-Mathius et al. (2006a) reported that incompatibility in interspecific micrografting between Cinchona ledgeriana and C. succirubra showed formation of 21 and $30 \mathrm{kD}$ protein and formation of stone cells in a union area.

\section{CONCLUSIONS}

Wedge or $\mathrm{V}$ graft was the best micrograft method for gaharu planlets, cultured in MS medium with the addition of $3 \mathrm{mg} / \mathrm{L} \mathrm{IBA}$, acclimatized in medium of husk chacoal : top soil $(1: 1)$ and incubated in plastic house.

Histology structure of compatible micrografting showed that shoot union area was the same as structure anatomy of seedlings, while histology structure of incompatible micrografting has a union area and necrotic layers along radial parts of shoot.

Union of vascular tissues have been confirmed after about three weeks in wellmatched grafts, and able to serve in the union of vascular tissues almost at once. Only a small number of short, irregular cells are then formed.

Compatible combination (Ac/Am) of micrografting showed that histology structure of union area is the same as histology structure of nonmicrografted planlet. While incompatible (Gv/Am) micrografting produced necrotic layer growth from pith and parenchymateous tissues of the wood in union area along the middle of radial shoot.

Protein pattern in compatible combination is the same as in seedlings. While protein pattern of incompatible combination produced a new protein band with molecular weight around 21 and $30 \mathrm{kD}$. 
Interspecific in vitro micrografting of agarwood - N. Toruan-Mathius et al.

\section{REFERENCES}

Anonim. 2002. Cultivating the world's most expensive incense. eNews 25 July 2002: 2-3. http://www.umn. edu/systemwids/enews /072502.html. [25 Agustus 2002].

Bertrand B. and H Etienne. 2001. Growth, production, and bean quality of Coffea Arabica as affected by interspecific grafting : Consequences for rootstock breeding. Journal of Horticulture Science : $36,269-273$.

Bradford, M.M. 1976. A rapid and sensitive methods for the quantitation of microgram quantities of protein utilizing the principle of protein-dye binding. Analytical Biochemistry 72:248-254.

CITES. 2003. Review of significant trade Aquilaria malaccensis. http//www.cites.org/eng/cttee/pc/14/ E.PC14.09.02.02.Az.pdf.

Da Costa , W.M., W. Gonlcalvez and.C. Fazouli. 1991. Producao do cafe' Mundo Novo em portaenxertos de Coffea canephora em area infestada com Meloidogyne incognita raca 1. Nematologia Brasileira 15:43-50.

De Abreu MF., NJC de Oliveira, M Santos and EL Pedrotti. 2003. Preliminaries histological studies from the micrografting of tissue cultured apple. Revista Brasileira Fruticultura 25(1) Jaboti Cabal April.

Errea P., L Garay and AJ.Marin. 2001. Early detection of graft incompatibility in Apricot (Prunus armeniaca) using in vitro techniques. Physiologia Planarum 112: 135-141.

Estrada-Luna AA., C Lopez-Peralpa and E Cardenas-Soriano. 2002. In vitro micro grafting and the histology of graft union formation of selected species of prikly pear caktus (Opuntia spp.). Scientia Horticulturae 92: 317-327.

Essau K. 1965. Plant anatomy, 2nd Edition. Wiley, New York.

Frandet A. 1983. Rejuvenation: Theory and practical experiences in clonal silviculture. In. Suffa,L., R.L. Rauter, W.W. Yeoman (Eds). Clonal forestry: its impact on tree improvement and our future forests. Pt.2. Toronto: Canadian Tree Improvement Association, 96-134.

Gunawan LW. 1992. Teknik kultur jaringan tumbuhan. Departemen Pendidikan dan Kebudayaan Direktorat Jenderal Pendidikan Tinggi; Pusat antar Universitas Bioteknologi, Bogor, Institut Pertanian Bogor.

Hartmann HT and DE Kester FT Davies. 1997. Plant propagation, principles and practice. Sixth Edition. Practice_Hall International, Inc. New Jersey. 770p

Hou D. 1960. Thymelaeaceae. In Van Steenis, C. G.G.J. (Ed.). Flora Malesiana. Gronigen: Walters-Noordhoff Publishing (1): 1-48.

Ishihara MT., T Tsuneya, M Shiga and KUneyama. 1991. Three Sesquiter-penes from Agarwood. Phytochemistry 20(7):1597-1599.

Jarausch, W. M Lansac, C. Bliot and F. Dosba .1999. Phytoplasm transmission by in vitro graft inoculation as a basis for a preliminary screening method for resistance in fruit trees. Plant Pathology, 48:283287.

Ji-Zhong Xu., Shi Bao-Sheng, MA Bao-kun, Guo Run-Fang, Li Xiao-Dong and Zhang Xian-Bin. 2002. Studies on the POD and IOD activities of the dwarfing stocks and the red fuji apple grafted on corresponding interstocks. China. Agriculture Science 1 (5): 562-567.

Jonart R. 1986. Micrografting and its application to tree improvement. In Bajaj, Y.P.S. (Ed). Biotechnology in agriculture and forestry. Trees I. Springer-Verlag, Berlin, Heidelberg, New York, Tokyo, 1986.

Kala RG., MP. Asokan, KP. Jayasree, S Sobha, R Jayasree, K Rekha and Thulaseedharan. 2002. Optimization of conditions for in vitro micrografting in rubber (Hevea brasiliensis). Indian Journal of Natural Rubber Research 15(2): 165-171. 
Kunoh H. 1990. Ultrastructure and Mobilization of ions near infection sites. In Annual Review of Phytopathology 28: 93-111.

Laemmli UK. 1970. Cleavage of structural proteins during the assembley of the head of bacteriophage T4. Nature 227:680-685.

LaFrankie. 1994. Population dynamics of some tropical trees that yields non-timber forest product. Economic Botany 48 (3): 301-309.

Lukman R., LW Gunawan, AS Abidin, R Megia and T.N.Praptosuwiryo 2005. Interspecific micrografting between Garcinia mangostana and Garcinia dulcis: biology and physiology point of view. Seameo Biotrop, Bogor Agricultural University, Center for Plant Conservation - Bogor Botanic Gardens LIPI Bogor Indonesia (In press 2005).

Murashige, T., and F. Skoog. 1960. A revised medium for rapid growth and bioassays with tobacco cultures. Physiologia Plantarum 15:473-497.

Moor R. 1991. Graft compatibilities in vitro: In: Biotechnology and forestry 17. High-tech micropropagation. Bajaj, Y.P.S.(Ed) Springer Verlag Berlin, p.71-84.

Oda M. 1995. New grafting methods for fruit-bearing vegetables in Japan. JARQ 29 187-194.

Parman T. Mulyaningsih and MYA. Rahman. 1996. Studi Etiologi Gubal Gaharu pada Pohon Ketimunan ( $A$. filaria). Temu Pakar Gaharu. Kanwil Dephut. Propinsi NTB, 11-12 April, 1996.

Rahman MA. and Basak. 1980. Agar Production in Agar Tree (A. agallocha Roxb.) by Artificial Inoculation and Wounding. Bano-Biggyan-Patrika $9: 87-93$. (Abstract).

Richardson, FV.., S Mac An tSaoir and BMR Harvey. 1996. A study of the graft union in in vitro micrografted apple. Plant Growth Regulator : 20:17-23.

Raghothama KG. 1999. Phosphate acquisition. Annual Review of Plant Physiology. Plant Molecular Biology 50: 665-693.

Rifải Faiz. 2003. Pengaruh batang bawah dan jenis bibit serta studi anatomi bidang penyambungan pada bibit grafting duku (Lansium domesticum Corr). [Skripsi] Jurusan Budidaya Pertanian Institut Pertanian Bogor.

Sanjaya B. Muthan, TS Rathore and VR Rai. 2006. Micropropagation of an endangered Indian sandalwood (Santalum album L.). Journal of Forestry Research 11(3):203-209.

SAS. 1996. The SAS system for Windows, Release 6.12, SAS Institute, Inc., Cary, NC.

Situmorang, J. 2000. Mikropropagasi kayu gaharu (Aquilaria sp.) asal Riau serta identifikasi sifat genetiknya . Thesis Master of Sains. Institut Pertanian Bogor.

Sobhana P., J Gopalakrishnan, J Jacob, and MR Sethuraj. 2001. Physiological and biochemical aspects of stockscion interaction in Hevea brasiliensis. Indian Journal of Natural Rubber Research 14(2):131136.

Soehartono T and AC Newton. 2001. Reproductive ecology of Aquilaria spp. In Indonesia. Forest Ecology \& Management $152(1-3): 59-71$.

Subansenee W. 1985. Fungi on agarwood (Aquilaria spp.). Royal Forestry Dept. Forest Product Research Div. Report on Minor Forest Product Research (Thailand). p.8-15. (Abstract).

Suparman. 2006. Teknologi budidaya tanaman gaharu untuk menuju sistem produksi gubal gaharu secara berkelanjutan. Workshop Gaharu Tingkat Nasional. Kerjasama Direktorat Hutan dan Perlindungan Hutan dan Konservasi Alam dan Asosiasi Pengusaha Eksportir Gaharu Indonesia. Surabaya, 11-13 September, 2006.

Tirtawinata MR. 2003. Kajian anatomi dan fisiologi sambung bibit manggis dengan beberapa anggota kerabat Clusiaceae. [Disertasi] Bogor : Program Doktor Institut Pertanian Bogor. 
Interspecific in vitro micrografting of agarwood - N. Toruan-Mathius et al.

Toruan-Mathius N., SA Adimihadja and I Boerhendhy. 1999. Rootstock-Scion interaction in Havea : Bark protein patterns and anatomy in correlation with genetic similarities. Menara Perkebunan 67(1): 1-2.

Toruan-Mathius N., Lukman, Agus-Purwito. 2006a. In vitro micrografting technique of Chincona succirubra and C. ledgeriana. Menara Perkebunan 74:1-10.

Toruan-Mathius N., J Situmorang, Yupi-Isnaini and Dewi-Rachmawati . 2006b. Database and the diversity of Aquilaria spp, Gyrinops spp and fungi associated with agarwood in Indonesia. Laporan Hasil Penelitian, DIPA, SEAMEO BIOTROP 2006.

Villain L., JL. Sarah, B Decazy, A Molina and S Sierra. 1996. Evaluation of grafting on Coffea canephora var. Robusta, and chemical treatment for control of Pratylenchus sp in C. Arabica cropping systems, p.407-422. In: Proc. $3^{\text {rd }}$ Intl. Nematol. Congr. Gosier, Guadeloupe, 7-12 July, 1996.

Van der Plank JE. 1978. Genetic and Molecular Basis of Plant Pathogenesis. Springer. Verlag, Berlin Heidelberg. New York. 